\title{
'ECCE FABULA!' PROBLEM-SOLVING BY NUMBERS IN THE CAROLINGIAN WORLD: THE CASE OF THE PROPOSITIONES AD ACUENDOS IUVENES
}

\author{
BY RUTGER KRAMER \\ Austrian Academy of Sciences
}

\begin{abstract}
'Ich habe bemerkt', sagte Herr K., 'daß wir viele abschrecken von unserer Lehre dadurch, daß wir auf alles eine Antwort wissen. Könnten wir nicht im Interesse der Propaganda eine Liste der Fragen aufstellen, die uns ganz ungelöst erscheinen? ? $^{1}$
\end{abstract}

Sometime in the mid-78os, Charlemagne, King of the Franks, had a letter composed in his name, and sent it to all of the abbots and bishops in his realm. His goals were as ambitious as they were reflective of a basic need to reinvigorate the pursuit of knowledge among his prelates. To start this endeavour, the letter states, it was vital to make sure that education in the realm was up to par:

For although correct conduct may be better than knowledge,

\footnotetext{
${ }^{1}$ Bertolt Brecht, Geschichten vom Herrn Keuner (Frankfurt am Main: Suhrkamp, 1971), ll. 239-43 ["'I have noticed", said Mr. K., "that we put many people off our teaching because we have an answer to everything. Could we not, in the interests of propaganda, draw up a list of questions that appear to us completely unsolved?"', Stories of Mr. Keuner, trans. by Martin Chalmers (San Francisco: City Lights Books, 2001), p. 18].
} 
nevertheless knowledge precedes conduct. Therefore, everyone ought to study what he desires to accomplish, so that so much the more fully the mind may know what ought to be done, as the tongue hastens in the praises of omnipotent God without the hindrances of errors. For since errors should be shunned by all men, so much the more ought they to be avoided as far as possible by those who are chosen for this very purpose alone, so that they ought to be the special servants of truth. ${ }^{2}$

With these words, the so-called Epistola De Litteris Colendis, or 'Letter on the Cultivation of Letters', set the programme for the cultural, religious, and educational reforms that would come to characterise the reign of Charlemagne and his successors. ${ }^{3}$ The letter is at once descriptive and prescriptive, and was intended to work on various levels. On the one hand, it was part of the Carolingian strategy to establish themselves as the undisputed rulers of the Frankish realms. ${ }^{4}$ Their hostile takeover of the Merovingian throne in the 750 s still required

2 Epistola de Litteris Colendis, ed. by Alfred Boretius, MGH Capitularia Regum Francorum 1 (Hannover, 1883), pp. 78-79; trans. in Charlemagne: Translated Sources, comp. by P. D. King (Kendal: P. D. King, 1987), pp. 23233.

${ }^{3}$ Thomas Martin, 'Bemerkungen Zur "Epistola de Litteris Colendis"', Archiv Für Diplomatik, 31 (1985), 227-72. Whereas this letter was intended to be sent to all the intellectuals in the realm, only a single copy is extant, directed at Abbot Baugulf of Fulda.

${ }^{4}$ Giles Brown, 'Introduction: The Carolingian Renaissance', in Carolingian Culture: Emulation and Innovation, ed. by Rosamond McKitterick (Cambridge: Cambridge University Press, 1993), pp. 1-51 (pp. 19-20); Rosamond McKitterick, Charlemagne: The Formation of a European Identity (Cambridge: Cambridge University Press, 2008), pp. 315-20. 
some justification, and Charlemagne and his entourage understood that this required more than mere military prowess - they also needed to cultivate an image of a king who was invested in conquering the hearts and minds of his subjects. $^{5}$ In this way, they could instil their ever-growing realm with a sense of 'togetherness' by insisting on a shared fount of knowledge - and a shared set of beliefs and practices

- that defined what it meant to be part of the ecclesia they were building. ${ }^{6}$ On the other hand, documents like the Epistola De Litteris Colendis also show a very palpable concern for the duties that came with the God-given office of kingship. ${ }^{7}$ To the Carolingians, reforms - or rather correctio, as contemporary individuals would refer to the phenomenon were about improving not just the lives, but also the afterlives of everyone living under their supervision. ${ }^{8}$ It was the king

${ }^{5}$ Rosamond McKitterick, 'The Illusion of Royal Power in the Carolingian Annals', English Historical Review, 115 (2000), 1-20; Paul Fouracre, 'The Long Shadow of the Merovingians', in Charlemagne: Empire and Society, ed. by Joanna Story (Manchester: Manchester University Press, 2005), pp. 5-21; Janet L. Nelson, 'Charlemagne and Empire', in The Long Morning of Medieval Europe: New Directions in Early Medieval Studies, ed. by Jennifer R. Davis and Michael McCormick (Farnham: Ashgate, 2008), pp. 223-34.

${ }^{6}$ Mayke de Jong, 'Sacrum Palatium et Ecclesia: L’autorité Religieuse Royale Sous les Carolingiens (790-840)', Annales: Histoire, Sciences Sociales, 58 (2003), 1243-69; Steffen Patzold, "Einheit" versus "Fraktionierung": Zur Symbolischen Und Institutionellen Integration des Frankenreichs im 8./9. Jahrhundert', in Visions of Community in the Post-Roman World: The West, Byzantium and the Islamic World, 300-110o (Farnham: Ashgate, 2012), pp. 375-90.

7 Mayke de Jong, 'Charlemagne's Church', in Charlemagne: Empire and Society, pp. 103-35.

${ }^{8}$ Percy Ernst Schramm, 'Karl Der Große: Denkart und Grundauffassungen

- Die von Ihm Bewirkte Correctio', Historische Zeitschrift, 198 (1964), 306- 
who bore the ultimate responsibility here, as he had to account for the misdeeds of all his subjects. ${ }^{9}$ Therefore, as Charlemagne quickly realised, it was equally important to make sure that those with whom he shared this responsibility were up to the task. ${ }^{10}$

Those possessing pastoral power were thus expected to have the knowledge and education to live up to what was expected of them.

For we desire you to be, as it is fitting that soldiers of the church should be, devout in mind, learned in discourse, chaste in conduct and eloquent in speech, so that whosoever shall seek to see you out of reverence of God [...] may be instructed by your wisdom, [...] and may go away joyfully giving thanks to omnipotent God. ${ }^{11}$

45; Nikolaus Staubach, “Populum Dei Ad Pascua Vitae Aeternae Ducere Studeatis": Aspekte der Karolingischen Pastoralreform', in La Pastorale Della Chiesa in Occidente dall'Eta Ottoniana al Concilio Lateranense IV (Milan: V\&P Università, 2004), pp. 27-54.

${ }^{9}$ Rob Meens, 'Politics, Mirrors of Princes and the Bible: Sins, Kings and the Well-Being of the Realm', Early Medieval Europe, 7 (1998), 345-57.

${ }^{10}$ Jennifer R. Davis, 'A Pattern for Power: Charlemagne's Delegation of Judicial Responsibilities', in The Long Morning of Medieval Europe: New Directions in Early Medieval Studies, ed. by Jennifer R. Davis and Michael McCormick (Aldershot: Burlington, 2008), pp. 235-46; for the situation under Louis the Pious, see Olivier Guillot, 'L'Exhortation au Partage des

Responsabilités entre L'empereur, l'Épiscopat et les Autres Sujets vers le Milieu du Règne de Louis Le Pieux', in Prédication et Propagande Au Moyen Âge: Islam, Byzance, Occident - Penn-Paris-Dumbarton Oaks Colloquia III, Session Des 20-25 Octobre 1980, ed. by George Makdisi, Dominique Sourdel, and Janine Sourdel-Thomine (Paris: Presses Universitaires de France, 1983), pp. 87-110.

${ }^{11}$ Epistola de Litteris Colendis, p. 79. 
In other words, the prelates who were admonished to take care of their own education were also reminded of their exemplary, pastoral function in the world. It was only by making sure that they possessed the knowledge and aptitude to be the best they could be, that they could properly impart this wisdom upon those who came to them looking for guidance. $^{12}$ Bishops, abbots, priests and monks were tasked with shepherding the Christian flock and overseeing the ecclesia - with the ruler acting as the overseer of the overseers, the teacher of the teachers, tasked with making sure everybody had the tools to be a good Christian in a good Christian Empire. ${ }^{13}$

Moreover, the Epistola De Litteris Colendis also makes clear in unequivocal terms that the stated ideals behind the envisaged correctio had an eschatological purpose as well. Explaining the need for a proper grounding in rhetoric and grammar, the letter reminds the audience that 'it is written:

"Either from thy words thou shalt be justified or from thy words thou shalt be condemned" (Mat 12.37)'. ${ }^{14}$ The intended audience, however, would no doubt have recognised this

\footnotetext{
${ }^{12}$ Carine van Rhijn, 'Priests and the Carolingian Reforms: The Bottlenecks of Local Correctio', in Texts and Identities in the Early Middle Ages, ed. by Richard Corradini et al. (Vienna: ÖAW Verlag, 2006), pp. 219-38.

13 Marios Costambeys, Matthew Innes, and Simon MacLean, The Carolingian World (Cambridge: Cambridge University Press, 2011), pp. 13153; Mayke de Jong, The Penitential State: Authority and Atonement in the Age of Louis the Pious, 814-840 (Cambridge: Cambridge University Press, 2009), pp. 112-47.

${ }^{14}$ Epistola de Litteris Colendis, p. 79.
} 
passage as coming from the Gospel of Matthew, where Christ uses this sentence to drive home the point that people would not only have to account for their misdeeds in the afterlife, but also for their bad thoughts and 'every thoughtless word they have spoken'. Education thus had become, quite literally, a matter of life and death for the caretakers of correctio. For those with a stake in the ecclesia, to strive for salvation meant to continuously strive to improve both one's self and one's subjects. ${ }^{15}$ The pursuit of knowledge in the Carolingian worldview had moral, pastoral, and even eschatological undertones that were fully in line with the holistic approach intellectuals took to correctio in the eighth and ninth centuries. ${ }^{16}$

Parallel to these lofty ideals, there was also a very practical reason to be concerned with correctio, a real-life advantage to be gained from having an educated clergy at work within the realm. This had everything to do with the many monasteries that dotted the Carolingian ecclesiastical landscape. These communities functioned not only as religious and intellectual nodal points in the early medieval world, but also, in the course of time, grew into the dominant economic and administrative centres in their respective regions. ${ }^{17}$ The stated

${ }^{15}$ John J. Contreni , 'The Pursuit of Knowledge in Caroligian Europe', in The Gentle Voices of Teachers: Aspects of Learning in the Carolingian Age, ed. by Richard E. Sullivan (Columbus: Ohio State University Press, 1995), pp. 106-41.

16 James Palmer, The Apocalypse in the Early Middle Ages (Cambridge: Cambridge University Press, 2014), pp. 130-58.

${ }^{17}$ The importance of monasteries is demonstrated with reference to Lorsch by Matthew Innes, 'Kings, Monks and Patrons: Political Identities and the Abbey of Lorsch', in La Royauté et Les Élites Dans l'Europe Carolingienne 
purpose of the major monasteries was to act as the purveyors of the 'power of prayer'. ${ }^{18}$ They were responsible for the upkeep of the liturgical ties that bound the ecclesia together, and for that, it was important to bolster their credibility through a continuous devotion to improvement, through education and self-reflection. ${ }^{19}$ Monks, just like priests and bishops, were encouraged to build up and maintain an 'internal cloister', to make sure they could interact with the secular world without harming their ability to intercede with the divine. ${ }^{20}$ This was a necessity, as these same monasteries would more often than not serve as the beating heart of their respective 'small worlds'. ${ }^{21}$ Although this clashed with the ideal that monks ought to stay within their chosen community at all times, the practical needs outweighed the theoretical requirements in this regard, and monks, especially from large

(début IXe Siècle aux Environs de 920), ed. by Régine Le Jan (Villeneuve d'Ascq: Université Charles-de-Gaulle/Lille, 1998), pp. 301-24.

${ }^{18}$ Mayke de Jong, 'Carolingian Monasticism: The Power of Prayer', in New Cambridge Encyclopedia of Medieval History C. 700-C. 900, 7 vols (Cambridge: Cambridge University Press, 1995), II, pp. 622-53.

19 Albrecht Diem, 'The Emergence of Monastic Schools: The Role of Alcuin', in Alcuin of York: Scholar at the Carolingian Court, ed. by L. A. J. R. Houwen and A. A. MacDonalc (Groningen: Egbert Forsten, 1998), pp. 2744; Susan Boynton, 'Training for the Liturgy as a Form of Monastic Education', in Medieval Monastic Education, ed. by George Ferzoco and Carolyn Muessig (London: Leicester University Press, 2000), pp. 7-20.

${ }^{20}$ Mayke de Jong, 'Internal Cloisters: The Case of Ekkehard's Casus Sancti Galli', in Grenze Und Differenz Im Friihen Mittelalter, ed. by Walter Pohl and Helmut Reimitz (Vienna: Verlag der ÖAW, 2000), pp. 209-21.

${ }^{21}$ A term borrowed from Wendy Davies, Small Worlds: The Village Community in Early Medieval Brittany (Los Angeles: University of California Press, 1988), who demonstrates the tremendous importance of a monastery for its surroundings. 
monasteries, would venture far beyond their own community to serve as local charter scribes, conflict arbitrators, and educators. $^{22}$

It is against this background that a rather curious text known as the Propositiones Ad Acuendos Iuvenes, 'Problems to Sharpen the Young', first saw the light of day at the turn of the ninth century. ${ }^{23}$ It is a collection of fifty-three or fifty-six mathematical problems (depending on the manuscript) commonly attributed to Alcuin, a Northumbrian deacon who had risen through the ranks to become abbot of the prestigious monastery of Marmoutier, near Tours, as well as one of the leading intellectuals at the Carolingian court. ${ }^{24}$ The modern tendency to place the Propositiones in a tradition

${ }^{22}$ M. M. Hildebrandt, The External School in Carolingian Society (Leiden: Brill, 1992).

23 'Propositiones Ad Acuendos Iuvenes', ed. by Menso Folkerts, in Die älteste mathematische Aufgabensammlung in lateinischer Sprache: Die Alkuin zugeschriebenen 'Propositiones ad Acuendos Iuvenes', (Berlin: Springer, 1978), 13-80; the translations presented in this article are based on the ones made by by John Hadley and David Singmaster, 'Problems to Sharpen the Young', The Mathematical Gazette, 76 (1992), 102-26. For an edition with a predominantly mathematical commentary, see Menso Folkerts and Helmut Gericke, 'Die Alkuin Zugeschriebenen "Propositiones Ad Acuendos Iuvenes"', in Science in Western and Easter Civilization in Carolingian Times, ed. by P. L. Butzer and D. Lohrmann (Basel: Birkhäuser, 1993), pp. 283-362. I will only refer to the number of the relevant propositio in the remainder of the article.

${ }^{24}$ For a full biographical overview, see Donald A. Bullough, Alcuin: Achievement and Reputation (Leiden: Brill, 2004). The discrepancy between the number of problems is due to the various manuscript transmissions, as explained by Folkerts, Die älteste mathematische Aufgabensammlung, pp. 17-30. 
springing from the interest in computational matters cultivated by the Venerable Bede, combined with Alcuin's Northumbrian origins and his place in Bede's intellectual genealogy, have made him a prime candidate for the authorship of this text. However, what evidence remains is largely circumstantial, and neither the philological characteristics nor the manuscript transmission of the Propositiones point unequivocally to a single author or collector, Alcuin or otherwise. ${ }^{25}$ Nonetheless, while the mind behind this text will most probably remain unknown, it seems clear that he (or she) was part of the intellectual world created by Alcuin. ${ }^{26}$ After all, it was he who penned the Epistola de Litteris Colendis in Charlemagne's name. ${ }^{27}$ And it was he who, in a famous letter to Charlemagne, applauded his ruler's insistence on continually asking questions in the course of a dispute at court, 'for to ask good questions is to teach', a point he also emphatically made in his letter of advice on the matter at hand.

\footnotetext{
${ }^{25}$ Bullough, Alcuin, p. 9.

${ }^{26}$ Folkerts and Gericke, pp. 282-83.

${ }^{27}$ Luitpold Wallach, 'Charlemagne's De Litteris Colendis and Alcuin: A Diplomatic-Historical Study', Speculum, 26 (1951), 288-305.

${ }^{28}$ Alcuin, 'Epistola 136', ed. by Ernst Dümmler, MGH, Epistola 4.2 (Berlin: Weidmann, 1895), pp. 205-10 (p. 205); Owen M. Phelan, The Formation of Christian Europe: The Carolingians, Baptism, and the Imperium Christianum (Oxford: Oxford University Press, 2014), pp. 143-46; Mary Alberi, “The Sword Which You Hold in Your Hand” : Alcuin's Exegesis of the Two Swords and the Lay Miles Christi', in The Study of the Bible in the Carolingian Era, ed. by Celia Chazelle and Burton Van Name Edwards (Turnhout: Brepols, 2003), pp. 117-31.
} 
Rather than dwell on questions of authorship, the remainder of this article shall focus on the Carolingian context of the Propositiones. More specifically, by looking at the way the text addresses its intended audience, my goal is to question whether this text should indeed be seen as a simple mathematical handbook, something of a mathematical curiosity - at worst an example of how dark the 'Dark Ages' actually were, at best a mathematical primer which had the teaching of computus as its

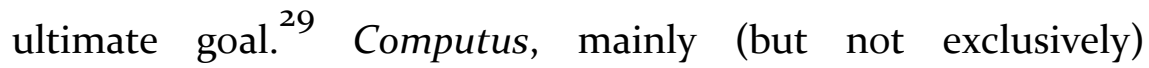
revolving around the calculation of Easter, was a topic of hot contention for centuries. ${ }^{30}$ In order to ensure that these calculations were done correctly - a matter of paramount importance to the Carolingian ecclesia - it would of course be necessary to have access to a group of clerics who were wellversed in the mathematics required to harmonise the lunar and solar cycles, arrive at a correct date each year, and fully understand the importance of what they were doing. ${ }^{31}$ However, given that many of the problems in the

\footnotetext{
${ }^{29}$ Kerstin Springsfeld, Alkuins Einfluß auf die Komputistik zur Zeit Karls des Großen (Stuttgart: Franz Steiner Verlag, 2002), esp. pp. 30, 115-16; Brigitte

Englisch, 'Alkuin Und Das "Quadrivium in Der Karolingerzeit", in Alcuin, de York à Tours: Écriture, Pouvoir et Réseaux Dans l'Europe Du Haut Moyen âge, ed. by Philippe Depreux and Bruno Judic, Annales de Bretagne et Des Pays de l'Ouest (Rennes: Presses Universitaires de Rennes, 2004), pp. 163-

74 .

${ }^{30}$ Stephen C. McCluskey, 'Natural Knowledge in the Early Middle Ages', in The Cambridge History of Science, ed. by David C. Lindberg and Michael H. Shank (Cambridge: Cambridge University Press, 2013), pp. 286-301 (pp. 294-98).

${ }^{31}$ Paul L. Butzer and Karl W. Butzer, 'Mathematics at Charlemagne's Court and its Transmission', in Court Culture in the Early Middle Ages: The Proceedings of the First Alcuin Conference, ed. by Catherine Cubitt, Studies
} 
Propositiones fall in the category of what is nowadays referred to as 'recreational mathematics', the question is whether computus was the sole concern of the author, or if the worldview sketched above may have impinged on the author and his audience in other ways as well. ${ }^{32}$ For instance, the purpose of many of the riddles presented in the text was to engage students intellectually, which may be a reflection of the social world of the elites at court, a world where wit was highly praised, and where scholarly prowess was an essential skill in the competition for Königsnähe. ${ }^{33}$ The problem-solving skills learnt through the Propositiones exist on the interface between practical issues and spiritual concerns. As such, the attempts to 'sharpen the young' as evidenced by the Propositiones speak volumes about the way the teachers of the

in the Early Middle Ages 3 (Turnhout: Brepols, 2003), pp. 77-89; Faith Wallis, "Number Mystique" in Early Medieval Computus Texts', in Mathematics and the Divine: A Historical Study, ed. by T. Koetsier and L. Bergmans (Amsterdam: Elsevier, 2005), pp. 179-99.

32 David Singmaster, 'The Utility of Recreational Mathematics', in The Lighter Side of Mathematics: Proceedings of the Eugène Strens Memorial Conference on Recreational Mathematics and its History, ed. by Richard K. Guy and Robert E. Woodrow (Cambridge: Cambridge University Press, 1996), pp. 340-45.

${ }^{33}$ Claire Tignolet, 'Jeux Poétiques à La Cour de Charlemagne: Compétition et Intégration', in Agon: La Competition Ve-XIIe Siècle, ed. by Francois Bougard, Régine Le Jan, and Thomas Lienhard, Collection Haut Moyen Age 17 (Turnhout: Brepols, 2012), pp. 221-34; Mary Garrison, 'The Social World of Alcuin: Nicknames at York and at the Carolingian Court', in Alcuin of York: Scholar at the Carolingian Court - Proceedings of the Third Germania Latina Conference Held at the University of Groningen, May 1995, ed. by Luuk Houwen and Alasdair A. MacDonald, Medievalia Groningiana 22 (Groningen: Forsten, 1998), pp. 59-79. 
era - be they monks or otherwise - saw education and the transfer of knowledge as a function of their pastoral responsibilities. $^{34}$

At first glance, the title covers most of the stated goals of the Propositiones: these are questions geared towards getting young monks, clerics, and other pupils acquainted with basic arithmetic, using the educational tool of the 'story problem' to help students frame their thoughts and to remind them that these problems existed outside of the book in the real world as well. $^{35}$ Nevertheless, some questions are closely associated with the more fanciful riddles that are nowadays seen as 'recreational'. For instance, the work is known for containing the earliest extant European 'river crossing problems', in which a farmer has to transport a wolf, a goat, and some cabbages in a boat that only holds two of each, or in which a

${ }^{34}$ Pierre Riché, 'Les Moines Bénédictins, Maîtres d'École, VIIe-XIe Siècles', in Benedictine Culture 750-1050, ed. by W. Lourdaux and D. Verhelst, Medievaelia Lovaniensia Series I, Studia XI (Leuven: Leuven University Press, 1983), pp. 96-113; Christopher M. Bellitto, 'Revisiting Ancient Practices: Priestly Training before Trent', in Medieval Education, ed. by Ronald B. Begley and Joseph W. Koterski (New York: Fordham University Press, 2005), pp. 35-49.

${ }^{35}$ Generally, see Eric de Corte, Brian Greer, and Lieven Verschaffel, Making Sense of Word Problems (Lisse: Swets \& Zeitlinger, 200o). The discrepancy between 'practical' and 'book' learning is still an issue in mathematics education: Al Rudnitsky, Susan Etheredge, Sue J.M. Freeman, and Therese Gilbert, 'Learning to Solve Addition and Subtraction Word Problems Through a Structure-plus-Writing Approach', Journal for Research in Mathematics Education, 26 (1995), 467-86 (p. 474). 
family has to make do with a rickety boat - the difficulty being that each of the members 'weighs as much as a cartload'. ${ }^{36}$

Other problems are more straightforward, but have equally fantastic scenarios. The very first, for example, starts by describing a scene in which 'a leech invited a slug for lunch a leuca away'. It then continues with the problem itself: '[b]ut he could only walk an inch a day. How many days will he have to walk for his meal? Speak, who can!' A solution is then presented: 'A leuca is 1500 paces, that is 7500 feet or 90,000 inches. It will take him as many days as inches, which makes 246 years and 210 days'. ${ }^{37}$ Behind the quirky story about two invertebrates having lunch hides a question that involves basic adding and multiplication, as well as a quick primer on what a leuca is, all skills that are transferable to the outside world. Likewise, the great variety of questions in the Propositiones, ranging from the straightforward to the whimsical, are all evidently intended for use in some sort of classroom, with the eventual goal of teaching children the type of mathematics and problem-solving skills that might be useful one day for an administrator, cleric, or pastor. ${ }^{38}$

Many of the Propositiones thus betray a preoccupation with practical applications that would operate in a world governed

36 Propositiones 17-20. See also Ralf Borndörfer, Martin Grötschel, and Andreas Löbel, ‘Alcuin's Transportation Problems and Integer Programing', Informationstechnik, 27 (1995), 1-28.

${ }^{37}$ Propositio 1.

${ }^{38}$ See Folkerts, 'Alkuin zugeschriebenen "Propositiones"', pp. 284-85. 
by agricultural concerns. ${ }^{39}$ These are the type of problems in which fields of various shapes and sizes are divided along various angles, for example, or in which the pay for workers building a house is calculated..$^{40}$ Another category consists of everyday scenes at a cattle market, and shows how price negotiations may be resolved in logical ways. In their own manner, these problems teach basic mathematical skills in such a way as to prepare the pupils for a role they will undoubtedly have to fulfil later in life - which includes taking into account the difference between 'poorer' and 'higher' quality pigs (deteriores and meliores). ${ }^{41}$ The same goes for a specific type of problem which is aimed at dividing inheritances or even 'calculating' increasingly complicated family relations. ${ }^{42}$ These challenges might seem exotic: 'If a widow and her daughter take a father and son in marriage, so that the son marries the mother and the father the daughter, what is the relationship of their sons?' ${ }^{43}$ But, given the importance of land possession and inheritance for the maintenance of family identity in the early medieval west, it is no surprise that problems of this type occur. ${ }^{44}$ At an even

39 See Chris Wickham, Framing the Early Middle Ages: Europe and the Mediterranean, 400-80o (Oxford: Oxford University Press, 2005), pp. 259$65,442-589$.

${ }^{40}$ Surface of fields: Propositiones 9, 10, 21, 22, 24, 28-30. Workers' payment:

Propositio 37.

${ }^{41}$ Propositiones 5, 6, 38, 39.

${ }^{42}$ Propositiones 11 (incl. 11a \& 11b), 12, 35 .

${ }^{43}$ Propositio 11 . There is no solution given to this problem.

${ }^{44}$ Matthew Innes, 'Keeping it in the Family: Women and Aristocratic Memory, 700-1200', in Medieval Memories; Men, Women and the Past, 70o- 
higher political level, the ability to properly determine genealogical descent could prevent a conflict from escalating. After all, wars have been fought over less. ${ }^{45}$

Such instances where problems go beyond simply tallying up numbers allow us to see more of the Sitz im Leben of the text. For example, the text also presents problems such as this: 'A man saw some horses at pasture and wished they were his, and that there were others with them that were his, the same number again, plus a quarter of the sum that would result, for then he could boast of having 100 horses. Try to discern, if you will, how many did the man see at pasture?' The answer - 40 is learned through the acquisition of division and multiplication skills. ${ }^{46}$ However, it is equally interesting that the question is framed in such a way that the horses are not the possession of the man in question, and that he is presented here not only as someone who wishes for things that are not his, but who also hopes to boast (glorior) of having more horses. Both of these traits would be sinful behaviour. Presented in this way, the propositio also provides

1300, ed. by Elisabeth van Houts (Harlow: Longman, 2001), pp. 17-35; Bullough, Alcuin, pp. 148-53.

45 See, for example, Ian Wood, 'Genealogy Defined by Women: The Pippinids', in Gender in the Early Medieval World: East and West, 300-9oo, ed. by Leslie Brubaker and Julia M. H. Smith (Cambridge: Cambridge University Press, 2004), pp. 234-56; but see the remarks by Walter Pohl, 'Genealogy: A Comparative Perspective from the Early Medieval West', in Meanings of Community across Medieval Eurasia: Comparative Approaches, ed. by Eirik Hovden, Christina Lutter, and Walter Pohl (Leiden: Brill, 2016), pp. 228-66 (pp. 253-55).

${ }^{46}$ Propositio 4. 
an opening for the teacher to explain the moral quandary here, adding ethical issues to his mathematical teachings.

Another propositio, one of the 'river-crossing problems', similarly touches upon moral issues disguised as a riddle. The problem goes: 'Three brothers, each with a sister, needed to cross a river. Each one of them coveted the sister of another. At the river they found only a small boat, in which only two of them could cross at a time. How did they cross the river without any of the women being defiled by the men? ${ }^{47}$ If such story problems are intended to make more sense by being somehow relatable to the audience, the presentation of the problem here shows an ongoing concern with gender relations and purity that were close to the daily life of monks and the clergy. ${ }^{48}$ This point is made even more strongly in the solution, which is presented in the first person. Suddenly, the pupils were encouraged to think about the purity of not just any woman, but of their own sisters: a touch of family honour is added, perhaps in order to motivate the students to work out a proper solution. ${ }^{49}$ Additionally, the phrasing of this

${ }^{47}$ Propositio 17.

${ }^{48}$ Mayke de Jong, 'Imitatio Morum: The Cloister and Clerical Purity in the Carolingian World', in Medieval Purity and Piety: Essays on Medieval Clerical Celibacy and Religious Reforms, ed. by Michael Frassetto (New York: Garland, 1998), pp. 49-8o.

${ }^{49}$ See the remarks by Régine Le Jan, 'Convents, Violence, and Competition for Power in Seventh-Century Francia', in Topographies of Power in the Early Middle Ages, ed. by Mayke de Jong, Frans Theuws, and Carine van Rhijn (Leiden: Brill, 2001), pp. 243-70 (pp. 262-63). The fact that the author speaks of 'my sister' precludes the option that this concerns monks and nuns, unless the author had pairs in mind who were siblings as well as members of monastic communities. 
problem and its solution imply that the student population envisaged consisted solely of men - an interesting insight into this author's vision of the Carolingian educational system. ${ }^{50}$

If a concern for the right order of things is visible in this problem about gender and family relations, this becomes a leitmotif in other questions as well. For instance, the text's version of the well-known rice-and-chessboard problem is about a king and his ever-expanding army: in addition to teaching students about large numbers (over a billion soldiers end up marching with the king), the basic premise here is that the king could indeed raise such an army, its necessity a sad fact of eighth-century life. ${ }^{51}$ It remains an open question whether or not the final tally is a reflection on the awesome might of the king's military or a warning against overestimating the capabilities of individual contributors to the army. At the very least, it is a reminder of the importance of the army for the self-identification of the Carolingian aristocracy. ${ }^{52}$ It could, again, be left to the teacher to reflect

${ }^{50}$ In spite of a dearth of sources, women did receive learning in the early middle ages: Valerie L. Garver, Women and Aristocratic Culture in the Carolingian World (Ithaca: Cornell University Press, 2009), pp. 122-25;

Valerie L. Garver, 'Learned Women? Liutberga and the Instruction of Carolingian Women', in Lay Intellectuals in the Carolingian World, ed. by Patrick Wormald and Janet L. Nelson (Cambridge: Cambridge University Press, 2003), pp. 121-38; Julia M. H. Smith, 'Gender and Ideology in the Early Middle Ages', in Gender and Christian Religion, ed. by R.N. Swanson, Studies in Church History 34 (Woodbridge: Boydell, 1998), pp. 51-73 (pp. 66-67).

${ }^{51}$ Propositio 13.

${ }^{52}$ Stuart Airlie, 'Towards a Carolingian Aristocracy', in Der Dynastiewechsel von 751: Vorgeschichte, Legitimationsstrategien Und Erinnerung, ed. by 
upon this, or it could be that the author of the Propositiones was inspired by such capitularies as the Capitula de Servitio Monasteriorum, which details different types of monastic (material) contributions to the emerging Carolingian state. ${ }^{53}$ Whatever the case, this version of the problem shows a reallife scenario in action, even though the eventual size of the army remains unrealistic at best.

Similar concerns with order may also be seen in two varieties of a division problem that is repeated more often throughout the text. Usually, the pupils are asked to divide food between men, women, and children in a household - and it is always the pater familias who does the distributing. ${ }^{54}$ While this already shows the 'ideal' family as envisaged by the author, it becomes even clearer in a problem concerning a bishop and his clergy: 'A certain bishop ordered that 12 loaves be divided among his clergy. He ordered that each priest should receive two loaves, each deacon one half, and each reader a quarter. There were as many clergy as loaves. How many priests, deacons and readers must there be? ${ }^{55}$ Both the question and the possible answers $(5,1$, and 6 ; or 4,8 , and o) imply an ecclesiastical hierarchy in which the bishop divides, and the relative 'value' of priests, deacons and lectors is expressed in terms of their daily allowance - again, a topic

Matthias Becher and Jörg Jarnut (Münster: Scriptorium, 2004), pp. 109-27 (p. 115).

53 Heinrich Wagner, 'Zur Notitia de Servitio Monasteriorum von 819', Deutsches Archiv Für Erforschung Des Mittelalters, 55 (1999), 417-38.

${ }^{54}$ Propositiones 32, 33, 33a, 34, 47, 51, 53. Bullough, Alcuin, pp. 146-47.

${ }^{55}$ Propositio 47. 
that was the subject of correctio as well. ${ }^{56}$ By comparing this to the very last problem, about monks, we see the relevance of this depiction: 'An abbot had 12 monks in his monastery. Calling his steward, he gave him 204 eggs and ordered that he should give equal shares to each monk. Thus he ordered that he should give 85 eggs to the 5 priests, and 68 to the four deacons and 51 to the three readers. Say, if you will, how many eggs went to each monk, so that none had too many or too few, but all received equal portions as described above'. ${ }^{57}$ The answer here is 17. More important, however, is that this answer belies the inherent equality of everyone inside a monastery. Idealistic though this may be, the author here juxtaposes the monastery's division scheme with that of the secular clergy, and teaches everyone a valuable lesson about order in the process, be it consciously or unconsciously. It is an ordering of the Church that wholly corresponds with the goals of the Carolingian correctio movement, and which is also reflected in a wide plethora of texts ranging from the everinfluential Regula Benedicti to the early ninth-century Institutio Canonicorum. ${ }^{58}$ From the point-of-view of the

${ }^{56}$ De Jong, 'Church', p. 111.

${ }^{57}$ Propositio 53.

${ }^{8}$ Adalbert De Vogüé, 'Structure et Gouvernement de La Communauté Monastique Chez Saint Benoît et Autour de Lui', in Atti Del $7^{\circ}$ Congresso Internazionale di Studi sull'Alto Medioevo (Spoleto: Centro Italiano di Studi sull'Alto Medioevo, 1982), pp. 563-98 (esp. pp. 581-86); Roger E. Reynolds, 'Clerics in the Early Middle Ages: Hierarchies and Functions', in Clerics in the Early Middle Ages: Hierarchy and Image, Variorum Collected Studies Series 669 (Aldershot: Ashgate, 1999), pp. 1-31 (pp. 27-28). 
author of the Propositiones it seems clear that teaching the right order of the world also began in the classroom.

'For those who want to ascend into the clerical order', wrote Hrabanus Maurus, a pupil of Alcuin, in 819, 'it would be appropriate to know and have at their disposal' all seven liberal arts. ${ }^{59}$ Grammar, rhetoric and logic were necessary for the exercise of the pastoral function of the clergy, to preach or to convert, but also to make sure they avoided the 'thoughtless words' they had been warned against in the Epistola De Litteris Colendis. Astronomy, music, geometry and arithmetic were needed so that students might take on the administrative duties expected of them in the agrarian world they lived in, but also so that they might grasp the complex mathematics involved in the calculation of Easter, and, more importantly, begin to fathom the order underpinning creation. ${ }^{60}$ As the hugely influential seventh-century bishop Isidore of Seville had already written in his Etymologies:

The reckoning of numbers ought not to be despised, for in many passages of sacred writings it elucidates how great a mystery they hold. Not for nothing it is said in praise of God (Wisdom 11.21), 'Thou hast ordered all things in measure, and number (numerus), and weight'. (...) Indeed, through numbers, we are provided with the means to avoid confusion. Remove numbers from all things,

\footnotetext{
${ }^{59}$ Hrabanus Maurus, De Institutione Clericorum, III, 13, ed. and trans. by Detlev Zimpel, Fontes Christiani 61 (Turnhout: Brepols, 2006).

${ }^{60}$ C. Stephen Jaeger, The Envy of Angels: Cathedral Schools and Social Ideals in Medieval Europe, 950-1200 (Philadelphia: University of Pennsylvania Press, 1994), pp. 21-24.
} 
and everything perishes. Take away the computation of time, and blind ignorance embraces all things; those who are ignorant of the method of calculation cannot be differentiated from the other animals. ${ }^{61}$

It is tempting to think that whoever was involved in the creation of the Propositiones had these words in the back of his mind. These were not just questions about measuring fields, they were meant to make one wonder about the awesome reality of creation.

The examples from the Propositiones treated in this article show how these story problems were embedded in their social world, and that this served a purpose beyond merely making the mathematical challenges relatable to the pupils. Pedagogically speaking, these stories were part of a discourse within which the pursuit, acquisition, and transmission of knowledge could easily take on moral or theological connotations in addition to those that were purely educational. The author was aware that his was a world where to teach meant to live well, and where living well meant to constantly strive for (self-)improvement.

Two final propositiones are especially interesting in this regard. The first concerns an ox that 'ploughs a field all day.

${ }^{61}$ Isidore, Etymologiarum sive Originum libri XX, III.4.4, ed. by Wallis M. Lindsay, Isidori Hispalensis Episcopi Etymologiarum Sive Originum Libri 20 (Oxford: Clarendon Press, 1911); trans. by Stephen A. Barney et al., The Etymologies of Isidore of Seville (Cambridge: Cambridge University Press, 2006), p. 90. 
How many footprints does he leave in the last furrow?' This is a trick question. The answer is that

an ox leaves no trace in the last furrow, because he precedes the plough. However many footprints he makes in the earth as he goes forward, the cultivating plough destroys them as it follows. Thus no footprint is revealed in the last furrow. ${ }^{62}$

Even more striking is another such riddle: 'A man has 300 pigs and orders that they are to be killed in 3 days, an odd number each day. What odd number of pigs must be killed each day?' Here, the answer is even more explicit. 'Ecce fabula!', the author joyously proclaims. 'This is nonsense! No-one can solve how to kill 300 or 30 pigs in three days, an odd number each day'. ${ }^{63}$ This could of course be an attempt at early medieval humour, an in-joke on the part of the author to confuse, amuse, and edify his readers. ${ }^{64}$ However, he does provide a clue at the end of this riddle, when he states that 'Fabulae like this are there in order to rebuke children'. The word used for 'rebuking' is increpare, a concept that, as shown by both Mayke de Jong and Irene van Renswoude, had a long pedigree in the Carolingian era. ${ }^{65}$ Using Biblical precedent from the

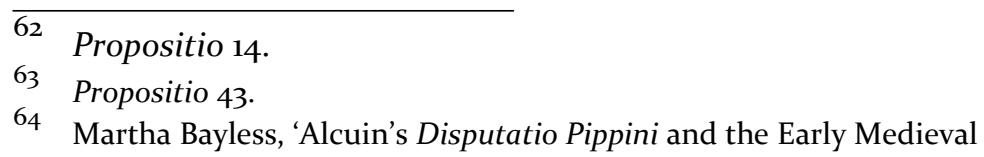

Riddle Tradition', in Humour, History and Politics in Late Antiquity and the Early Middle Ages, ed. by Guy Halsall (Cambridge: Cambridge University Press, 2002), pp. 157-78.

${ }^{65}$ De Jong, Penitential State, pp. 142-47; Irene van Renswoude, 'Licence to Speak: The Rhetoric of Free Speech in Late Antiquity and the Early Middle Ages' (doctoral thesis, University of Utrecht, 2011), pp. 148-51, 274-75. 
Psalms, the books of Kings, and also the New Testament, Carolingian intellectuals had made increpatio an integral part of the rhetorical devices at their disposal. It was the type of rebuke that was seemingly harsh, but which nonetheless needed to be given in order to teach its recipient a valuable lesson or set them on the right path. Demons could be rebuked, as could mere mortals, including kings and emperors. The Old Testament King David had already been the subject of such a rebuke, but the Carolingian ideal was based to a large extent on the model provided by Ambrose of Milan's conflict with the Emperor Theodosius I as well: the beneficial effects of 'an increpatio delivered by a man flourishing with virtue' were already recognised in the late sixth century, as attested in the Historia Tripartita compiled by Cassiodorus. ${ }^{66}$ In order to keep their flock on the straight and narrow, the pastors of the Carolingian ecclesia had rediscovered and taken up this rallying cry, and so increpatio had become part of the repertoire of teachers and pastors, students and sheep alike. ${ }^{67}$

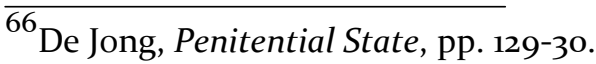

${ }^{6}$ Van Renswoude, 'License to Speak', pp. 371-82; Desirée Scholten, 'Cassiodorus's Historia tripartita before the earliest extant manuscripts', in The Resources of the Past in Early Medieval Europe, ed. by Clemens Gantner, Rosamond McKitterick, and Sven Meeder (Cambridge: Cambridge University Press, 2015), pp. 34-50. Specifically on the position of Alcuin in this discourse, see Mary Garrison, 'An Aspect of Alcuin: "Tuus Albinus” - Peevish Egotist? Or Parrhesiast?', in Ego Trouble: Authors and Their Identities in the Early Middle Ages, ed. by Richard Corradini et al., Forschungen Zur Geschichte Des Mittelalters 15 (Wien: ÖAW Verlag, 2010), pp. 137-52.
} 
While this particular propositio about the impossible division of pigs need not necessarily be part of the author's political agenda, the little remark in the 'answer' does provide an interesting clue about the didactic intentions of the author. Teaching numbers was not just about solving riddles or finding solutions to practical issues. It was also a way to teach people about the order underlying it all, regardless of whether they realised this or not. To be rebuked, to be taught, was not just for the pupils' benefit anymore: both teachers and students would in theory end up being better people through the exchange of knowledge. Part of this would be the realisation that in the greater scheme of things, some problems cannot be solved by mere logic.

If the study of mathematics appears to be a study of absolutes, it appears, by extension, to be a study of what is essentially unreal. ${ }^{68}$ Numbers turn into formulas, formulas turn into models, models turn into ideals, and these ideals end up as the building blocks of the structures that allow people to predict the behaviour of numbers, particles, and, to a certain extent, even people. The study of history, on the other hand, eschews this search for the absolute in favour of a deeper understanding of the stories people tell to make sense of their

68 For the way Newton saw in mathematics a way to perceive God's creation in absolute terms, see C. de Pater, 'An Ocean of Truth', in Mathematics and the Divine: A Historical Study, ed. by T. Koetsier and L. Bergmans (Amsterdam: Elsevier, 2005), pp. 459-84. Cf. Richard E. Grandy, 'Constructivisms and Objectivity: Disentangling Metaphysics from Pedagogy', in Constructivism in Science Education: A Philosophical Examination, ed. by Michael R. Matthews (Dordrecht: Springer, 1998), pp. 113-25, esp. p. 120 on the role of (knowledge of) history in science teaching. 
observations. The pursuit of knowledge in this discipline is a pursuit of the social logic of a given source, and mutatis mutandis, a desire to understand the human need to structure the world around them. Sometimes when these two overlap, misunderstandings about the respective disciplines' epistemological intentions may lead to mutually confusing conversations. ${ }^{69}$ The lines between these two seemingly extreme genres are blurred to the point of overlap in works like the Propositiones, a text that is as mathematically viable as it is socially conscious. ${ }^{70}$ The 'snapshot' it provides of the educational concerns of the author shows that this is recreational mathematics to the extent that the text uses mathematical problems not just to educate young pupils, but to literally 're-create' their world. ${ }^{71}$ The author of the Propositiones had set out not just to teach basic mathematics that would provide his students with the skills necessary to deal with everyday life in a monastery: he, too, fits within a trend where education increasingly 'transcended

\footnotetext{
${ }^{69}$ One such case is described in A. Sierpinska, 'Humanities students \& epistemological obstacles related to limits', Educational Studies in Mathematics, 18 (1987), 371-97.

$7^{70}$ As proposed by Clifford Geertz, Local Knowledge: Further Essays in Interpretive Anthropology (New York: Basic Books, 1983), p. 20; cf. C. Konold and D. K. Johnson, 'Philosophical and Psychological Aspects of Constructivism', in Epistemological Foundations of Mathematical Experience, ed. by Leslie P. Steffe (New York: Springer, 1991), 1-13.

${ }^{71}$ Carine van Rhijn, 'The Local Church, Priests' Handbooks and Pastoral Care in the Carolingian Period', in Chiese Locali e Chiese Regionali nell'Alto Medioevo (Spoleto: Fondazione Centro Italiano di Studi sull'Alto Medioevo, 2014), pp. 689-710.
} 
utilitarianism'. $^{72}$ In part, the Propositiones intrinsically warn students about what has later been called the 'suspension of sense-making' - the idea that (mathematical) problems need to be solved even if the answer cannot be realised in the world. $^{73}$ Rather than simply offering a course in problemsolving by numbers, or relying solely on repetition as a teaching tool, the Propositiones ad Acuendos Iuvenes also advocated a system of learning where minds would indeed be sharpened by analytical skills, instead of being dulled by repetition. $^{74}$

${ }^{72}$ Michael H. Shank, 'Schools and Universities in Medieval Latin Science', in The Cambridge History of Science, ed. by David C. Lindberg and Michael H. Shank (Cambridge: Cambridge University Press, 2013), pp. 207-39 (p. 211).

${ }^{73}$ Proposed by A. H. Schoenfeld, 'On mathematics as sense-making: An informal attack on the unfortunate divorce of formal and informal mathematics', in Informal Reasoning and Education, ed. by J. F. Voss, D. N. Perkins, and J. W. Segal (London: Routledge, 1991), pp. 311-43.

${ }^{74} \mathrm{Cf}$. the observations on Cluniac education in Isabelle Cochelin, 'Besides the Book: Using the Body to Mould the Mind - Cluny in the Tenth and Eleventh Centuries', in Medieval Monastic Education, ed. by George Fercozo and Carolyn Muessig (London: Leicester University Press, 2000), pp. 21-34, where the keywords were passivity, imitation, and punishment.

The research for this article was funded by the SFB Visions of Community (FWF Austrian Science Fund F42). Special thanks to Marcel Haas for helping me make sense of the mathematics in the source text. 